\title{
mGlu5 receptor functional interactions and addiction
}

\author{
Robyn M. Brown ${ }^{1,2 \dagger}$, Sanam Mustafa ${ }^{3 \dagger}$, Mohammed Akli Ayoub ${ }^{3}$, Peter R. Dodd ${ }^{4}$, Kevin D. G. Pfleger ${ }^{3,5 *}$ and \\ Andrew J. Lawrence ${ }^{1,2 *}$ \\ ${ }^{1}$ Addiction Neuroscience, Behavioural Neuroscience, Florey Neuroscience Institutes, University of Melbourne, Parkville, VIC, Australia \\ ${ }^{2}$ Centre for Neuroscience, University of Melbourne, Parkville, VIC, Australia \\ ${ }^{3}$ Laboratory for Molecular Endocrinology-GPCRs, Western Australian Institute for Medical Research and Centre for Medical Research, The University of Western \\ Australia, Perth, WA, Australia \\ ${ }^{4}$ School of Chemistry and Molecular Biosciences, University of Queensland, Brisbane, QLD, Australia \\ ${ }^{5}$ Dimerix Bioscience Pty Ltd., Perth, WA, Australia
}

Edited by:

Trevor Sharp, University of Oxford, UK

Reviewed by:

Li Zhang, NIAA-NIH, USA

Jason B. Wu, Cedars-Sinai Medical

Center, USA

*Correspondence:

Kevin D. G. Pfleger, Western

Australian Institute for Medical

Research, B Block, OEll Medical

Centre, Nedlands, Perth, WA 6009

Australia.

e-mail:kevin.pfleger@

waimr.uwa.edu.au;

Andrew J. Lawrence, Florey

Neuroscience Institutes, Melbourne

Brain Centre, University of

Melbourne, Parkville, VIC 3010 ,

Australia.

e-mail: andrew.lawrence@

florey.edu.au

${ }^{\dagger}$ Robyn M. Brown and Sanam

Mustafa have contributed equally to this work.
The idea of "receptor mosaics" is that proteins may form complex and dynamic networks with respect to time and composition. These have the potential to markedly expand the diversity and specificity of G protein-coupled receptors (GPCR) signaling, particularly in neural cells, where a few key receptors have been implicated in many neurological and psychiatric disorders, including addiction. Metabotropic glutamate type 5 receptors (mGlu5) can form complexes with other GPCRs, including adenosine $A_{2 A}$ and dopamine $D_{2}$ receptors. mGlu5-containing complexes have been reported in the striatum, a brain region critical for mediating the rewarding and incentive motivational properties of drugs of abuse. mGlu5containing complexes and/or downstream interactions between divergent receptors may play roles in addiction-relevant behaviors. Interactions between $\mathrm{mGlu} 5$ receptors and other GPCRs can regulate the rewarding and conditioned effects of drugs as well as drug-seeking behaviors. mGlu5 complexes may influence striatal function, including GABAergic output of striatopallidal neurons and glutamatergic input from corticostriatal afferents. Given their discrete localization, mGlu5-[non-mGlu5] receptor interactions and/or mGlu5-containing complexes may minimize off-target effects and thus provide a novel avenue for drug discovery. The therapeutic targeting of receptor-receptor functional interactions and/or receptor mosaics in a tissue specific or temporal manner (for example, a sub-population of receptors in a "pathological state") might reduce detrimental side effects that may otherwise impair vital brain functions.

Keywords: metabotropic glutamate receptor, drug addiction, drug-seeking, heteromer, receptor interaction, metabotropic glutamate receptor type 5 , hub receptor

\section{DRUG ADDICTION}

Drug and alcohol addiction is a major problem in Western society where substance abuse is associated with considerable social, medical, and financial costs (Collins and Lapsley, 2002). It has been estimated that annually around $\$ 7.5$ billion is associated with alcohol and alcohol-related problems in Australia and about $5 \%$ of the total annual mortality is due to this (Collins and Lapsley, 2002). The Australian Institute of Health and Welfare estimated that in 2004, more than 56,000 people had used opiates in the previous 12 months and around $1 \%$ of the population had used cocaine (AIHW 2005). Due to the impact on society and limited success of current therapies to treat addiction, extensive research into the pathophysiology underlying alcoholism and drug abuse is ongoing. In particular, research efforts are focused toward understanding the persistent vulnerability to relapse displayed by drug-addicted individuals despite months or even years of abstinence (Gossop et al., 1989; Dejong, 1994; Jupp and Lawrence, 2009).

Current preclinical research into potential treatments for addiction is focused on gaining a greater understanding of the neurobiological mechanisms underpinning both relapse vulnerability and the transition from casual to compulsive drug use. This knowledge will enable the identification of potential therapeutic targets for drug development. At present there is a paucity of pharmacotherapies on the market for the treatment of addictions; none of which are particularly effective and involve multiple off-target effects (Jupp and Lawrence, 2009). For this reason it is vital that new therapeutic targets are identified that have potential in this regard. Complexes containing the metabotropic glutamate receptor type 5 (mGlu5), and/or functional interactions between mGlu5 and other G protein-coupled receptors (GPCRs), represent a novel therapeutic option worthy of investigation due to the possibility of limiting off-target effects. mGlu5 has been implicated in numerous central processes, thus targeting mGlu5-containing complexes/functional receptor interactions that are restricted to addiction-relevant brain areas provide an avenue to selectively target those mGlu5 involved in reward and drug-seeking behavior (Bird and Lawrence, 2009b).

\section{mGlu5 AND ADDICTION}

A variety of GPCRs have been shown to play critical roles in the reinforcing and motivational properties of drugs, drug-induced 
plasticity and drug-seeking behavior (Traynor, 2010). A substantial body of evidence exists which implicates metabotropic glutamate receptors in many of these facets of drug addiction (Bird and Lawrence, 2009a; Olive, 2009) and among them mGlu5 seems to play a significant role. mGlu5 belongs to a distinct family of eight GPCRs that are activated by L-glutamate, the major fast excitatory neurotransmitter in the central nervous system (CNS). At the signaling level, mGlu5 is known to be associated with phosphoinositide hydrolysis and the activation of phospholipase $\mathrm{C}$, stimulation of adenylate cyclase and inhibition of voltage-operated calcium channels (Dhami and Ferguson, 2006). Signaling via mGlu5 is thought to play a role in synaptic plasticity, ultimately affecting learning and memory, neuronal development and neurodegeneration (Lu et al., 1997). It is also thought to have a role in a number of behaviors including stress responses, anxiety-like, and depressive-like behavior (Tatarczynska et al., 2001). mGlu5 is highly expressed in the olfactory bulb and tubercle, dorsal striatum, nucleus accumbens, cerebral cortex, hippocampal formation, and amygdala (Shigemoto et al., 1993; Romano et al., 1995). In the striatum, mGlu5 is located primarily in the perisynaptic ring and at the postsynaptic density (Kennedy, 2000; Smith et al., 2000), including striatal projection neurons containing enkephalin (Testa et al., 1995). Evidence of presynaptic localization of mGlu5 on cortical inputs to the striatum also exists (Romano et al., 1995; Rodrigues et al., 2005). The mGlu5 receptor is structurally linked to the NMDA receptor via a protein scaffold (Naisbitt et al., 1999) and functional interactions have been demonstrated between the two receptors (Attucci et al., 2001). Thus, mGlu5 receptors are perfectly positioned to influence the mesolimbic, corticotegmental, and corticostriatal pathways known to be critical for the actions of drugs of abuse and drug-induced plasticity.

The first evidence to suggest a role for mGlu5 in the rewarding properties of drugs of abuse was provided by Chiamulera et al. (2001) who reported that mice lacking mGlu5 failed to intravenously self-administer a range of doses of cocaine and failed to show any hyperactivity after acute administration of the drug. Subsequent pharmacological studies have supported these initial findings. Antagonism of mGlu 5 can reduce the self-administration of multiple drugs of abuse as well as reinstatement of drug-seeking, indicating a facilitatory role for this receptor in these behaviors (Olive, 2009). For example, the mGlu5 antagonists 2-methyl-6(phenylethynyl)-pyridine (MPEP) and 3-[(2-methyl-1,3-thiazol4-yl)ethynyl] pyridine (MTEP) reduce self-administration of alcohol, cocaine, and nicotine in rats (Kenny et al., 2003; Backstrom et al., 2004; Cowen et al., 2005) as well as alcohol and morphine in mice (Cowen et al., 2007; Brown et al., 2011b). These antagonists can also attenuate reinstatement of alcohol(Backstrom et al., 2004), cocaine- (Backstrom and Hyytia, 2006), nicotine- (Bespalov et al., 2005), opiate- (Brown et al., 2011b), and methamphetamine-seeking (Gass et al., 2009) in animal models of relapse, indicating a clear role for mGlu5 in drug-seeking behavior across a broad range of reinforcers. Genetic mouse models have also implicated mGlu5 in the reinforcing and motivational properties of drugs of abuse. In addition to the original work by Chiamulera and colleagues, deletion of the mGlu5 gene results in altered central reward processing in the case of ethanol
(Bird et al., 2008) and an absence of drug-induced synaptic plasticity in the ventral tegmental area in the case of cocaine (Bird et al., 2010). Thus, the putative involvement of mGlu5 in addictive behavior suggests that selective inhibition of this receptor may provide an exciting new approach for treatment of addictive disorders.

More recently evidence has been forthcoming which implicates mGlu5 in associative reward learning processes more generally. Published reports suggest systemic administration of the selective mGlu5 antagonist MTEP prior to conditioning disrupts the expression of conditioned reinforcement by food delivery (O'Connor et al., 2010). This suggests a critical role for mGlu5 in the acquisition of incentive properties by a conditioned stimulus (O'Connor et al., 2010); an observation which is supported by the finding that mice with knockdown of mGlu5 in striatal $\mathrm{D}_{1}$-expressing neurons exhibit diminished cue-induced cocaineseeking, as well as impaired incentive learning (Novak et al., 2010). Hence mGlu5 may play a central role in associative reward learning processes (Novak et al., 2010) in addition to the rewarding properties of drugs of abuse. This possible role in incentive learning is not inconsistent with the involvement of mGlu5 in cue-induced drugseeking behavior (Backstrom et al., 2004; Backstrom and Hyytia, 2006). Indeed, in the operant conditioning paradigm, the discrete cue is a conditioned stimulus and as such needs to acquire incentive motivational properties in order to elicit drug-seeking upon re-presentation. Collectively, these studies provide further insight into the potentially complex role of mGlu5 in both reward and reward learning.

A role for mGlu5 in extinction learning relevant to drug use and drug-associated cues has also been established by recent research using positive allosteric modulators of mGlu5 (Cleva and Olive, 2011). The first mGlu5 positive allosteric modulators to be characterized were 3-cyano- $N$-(1,3-diphenyl1H-pyrazol-5-yl)benzamide (CDPPB; Lindsley et al., 2004) and $S$-(4-fluoro-phenyl) [3-[3-(4-fluoro-phenyl)-1,2,4-oxadiazol5-yl]piperidin-1-yl]methanone (ADX47273; Liu et al., 2008) and were suggested to be beneficial in alleviating the cognitive deficits associated with chronic drug abuse (Reichel et al., 2011). Studies using animal models of addiction have also shown that CDPPB facilitates extinction of both cocaine-conditioned place preference (Gass and Olive, 2009) and operant responding for cocaine (Cleva et al., 2011). This is supported by observations from our laboratory, which demonstrate deficits in extinction learning in mice lacking mGlu5 (Lawrence Laboratory, unpublished observations). Therefore, positive allosteric modulators of mGlu5 have potential use as pharmacological adjuncts to cue exposure therapy in the treatment of drug addiction, with the potential benefit of reversing cognitive deficits associated with chronic drug use (Cleva and Olive, 2011). Recently, a range of compounds that selectively inhibit mGlu5 function have been published and tested in various neurological disorder models and some of them exhibit good tolerability, long-term action, and oral bioavailability (Keywood et al., 2009; Zerbib et al., 2010; Lindemann et al., 2011). Consequently, there is a promising future for the development of new treatments for addiction based on both positive and negative allosteric modulation of mGlu5. 


\section{GPCR HETEROMERIZATION AND $\mathrm{A}_{2 \mathrm{~A}} \mathrm{R}-\mathrm{D}_{2} \mathrm{R}-\mathrm{mGlu} 5$ COMPLEXES}

In order to maintain the speed and subtly of neuronal signal transmission, intramembrane protein-protein interactions are likely to play a role (Vilardaga et al., 2008). Consequently, researchers in the GPCR field are now focusing their efforts on understanding GPCR signaling and function in the context of higher-order structures and not just monomers. Textbooks describing GPCR signaling as a linear cascade, where agonist activation results in the receptor coupling to one $G$ protein and therefore the activation of one signaling pathway, are now being updated to include receptor homomers (macromolecular complexes made up of two or more identical functional receptor units) and receptor heteromers (macromolecular complexes composed of at least two different functional receptor units with biochemical properties that are demonstrably different from those of their individual components; Ferre et al., 2009). Heteromerization not only provides a potential mechanism for increased signaling diversity, but also specificity by, for example, allowing the development of drugs to target in a tissue selective manner and thereby minimize off-target effects (Mustafa et al., 2010). Indeed, there are now numerous examples of physiologically relevant GPCR heteromers (Dalrymple et al., 2008), particularly in the CNS (Albizu et al., 2010), and new methodologies are being developed to investigate such complexes (Mustafa et al., 2010).

Dopaminergic and glutamatergic inputs converge in the dendritic spines of $\gamma$-aminobutyric acid (GABA)ergic medium spiny neurons (Totterdell and Smith, 1989; Sesack and Pickel, 1992) which constitute more than $90 \%$ of the neuronal population of the striatum (Smith and Bolam, 1990). Dopamine release in the striatum activates two classes of GPCRs that are expressed by distinct subpopulations of medium spiny neurons. Dopamine $\mathrm{D}_{1}$ receptors $\left(D_{1} R\right)$ are localized on the striatonigral neurons of the direct pathway whereas dopamine $D_{2}$ receptors $\left(D_{2} R\right)$ are expressed by the striatopallidal neurons of the indirect pathway (Gerfen, 1992; Le Moine and Bloch, 1995). $D_{2}$ Rs are coupled to $G_{\alpha i}$, and activation of these receptors triggers a cascade of signaling pathways, reducing cAMP production and protein kinase A (PKA) activity and activating phospholipase $\mathrm{C}$ (PLC)-dependent processes as well as the release of $\mathrm{Ca}^{2+}$ from internal stores (Missale et al., 1998). $\mathrm{D}_{2} \mathrm{R}$ has been linked to a number of behavioral disorders, including Parkinson's disease, obsessive-compulsive disorder, addiction, and schizophrenia (Bonci and Hopf, 2005; Kreitzer and Malenka, 2008). Treatments targeting dopaminergic signaling have utilized dopamine receptor agonists to alleviate symptoms of hypokinesia associated with Parkinson's disease, and dopamine receptor antagonists to treat hallucinations and delusions in schizophrenic patients (Missale et al., 1998). However, side effects have been associated with both therapies, presumably due to the difficulty in re-establishing the balance in dopamine signaling required for appropriate physiological function.

Adenosine is often described as a neuromodulator, which acts on a family of four adenosine receptors: $A_{1}, A_{2 A}, A_{2 B}$, and $A_{3}$ receptors (Fredholm et al., 1994, 2001b). Of the four known adenosine receptors, $A_{1}$ and $A_{2 A}$ receptors are primarily responsible for the central effects of adenosine (Fredholm et al., 2001a). $A_{1}$ receptors are widely distributed in the brain (Fastbom et al., 1987; Fredholm et al., 2001a) whereas $A_{2 A}$ receptors are highly enriched in the terminal regions of ascending dopamine projections, concentrated in the dendritic spines of striatopallidal neurons, particularly in the vicinity of glutamatergic synapses (Fink et al., 1992; Svenningsson et al., 1997; Hettinger et al., 2001; Rosin et al., 2003). Adenosine A $2 \mathrm{~A}$ receptors are also found presynaptically in glutamatergic, but not in dopaminergic, terminals although with lower density (Hettinger et al., 2001; Rosin et al., 2003). Therefore, it has been suggested that the $A_{2 A}$ receptor plays a role in the fine-tuning modulation of glutamatergic neurotransmission onto striatal GABAergic neurons both at the postsynaptic and presynaptic level (Hettinger et al., 2001; Ciruela et al., 2006; Ferre et al., 2007b). Recently, presynaptic $\mathrm{A}_{2 \mathrm{~A}}$ receptors were shown to be preferentially localized in cortical glutamatergic terminals that contact medium spiny neurons of the direct pathway (Quiroz et al., 2009), while their postsynaptic counterparts are located on striatopallidal neurons of the indirect pathway. Thus adenosine acting at $\mathrm{A}_{2 \mathrm{~A}}$ receptors has the capacity to modulate neurotransmission of both output pathways of the basal ganglia. Signaling via the $\mathrm{A}_{2 \mathrm{~A}}$ receptor has been implicated in the reinforcing properties of multiple drugs of abuse (Brown and Short, 2008). For example, in mice lacking the $A_{2 A}$ receptor, a reduction in self-administration of morphine has been reported (Brown et al., 2009). Similarly, $A_{2 A} R$ antagonists have also been reported to reduce alcohol-seeking and opiate-seeking behavior in rats (Arolfo et al., 2004; Yao et al., 2006).

A remarkable feature of the two striatal output pathways is the segregation of adenosine and dopamine receptors. GABAergic/enkephalinergic neurons predominantly express adenosine $A_{2 A}$ (stimulatory, coupled to $G_{s} / G_{\text {olf }}$ ) and dopamine $\mathrm{D}_{2}$ (inhibitory, coupled to $\mathrm{G}_{\mathrm{i}}$ ) receptors, while GABAergic/dynorphinergic neurons predominantly express adenosine $A_{1}$ (inhibitory, coupled to $\mathrm{G}_{\mathrm{i}}$ ) and dopamine $\mathrm{D}_{1}$ (stimulatory, coupled to $G_{s}$ ) receptors (Schiffmann et al., 2007). It is not surprising therefore, that evidence has accumulated documenting interactions between these GPCRs in relation to striatal GABAergic efferent neuron function (Ferre et al., 2007c; Schiffmann et al., 2007).

These interactions have been reported to include direct receptor-receptor interactions as well as interactions at the second messenger and behavioral levels, all of which have been reviewed elsewhere (Ferre et al., 1994, 2004; Fredholm and Svenningsson, 2003; Fuxe et al., 2003). The $A_{2 A}-D_{2}$ interaction is predominantly found to be antagonistic as activation of $A_{2 A} R$ reduces $\mathrm{D}_{2} \mathrm{R}$ binding, coupling, signaling as well as behavioral effects; thus $\mathrm{D}_{2} \mathrm{R}$ exerts a tonic inhibition on striatopallidal neurons which $\mathrm{A}_{2 \mathrm{~A}} \mathrm{R}$ activation antagonizes (see reviews above). Evidence for the existence of heteromers containing $A_{2 A}$ and $D_{2}$ receptors in expression systems has been provided by means of coimmunoprecipitation and resonance energy transfer (RET) techniques such as bioluminescence-RET (BRET) and fluorescenceRET (FRET; Canals et al., 2003; Cabello et al., 2009). In terms of their localization in the striatum, ultrastructural and confocal analysis indicate this to be mainly on dendritic spines in the perisynaptic zones of dopamine terminals and glutamatergic synapses in striatopallidal neurons (Fuxe et al., 2010). In addition, interactions involving the $A_{2 A} R$ have been described for other receptors, including adenosine $A_{1}$, cannabinoid $C_{1}$ and, most 
relevant to this review, mGlu5 (Ferre et al., 2007a; Schiffmann et al., 2007).

In the striatum mGlu5 is expressed postsynaptically on both types of striatal GABAergic efferent neuron and potentially presynaptically on glutamatergic terminals (Romano et al., 1995; Tallaksen-Greene et al., 1998; Smith et al., 2000). In striatopallidal neurons, similar to $A_{2 \mathrm{~A}} \mathrm{R}$, mGlu5 is predominantly found postsynaptically and perisynaptically to asymmetric synapses (Smith et al., 2000). This similarity in anatomical location led Ferre et al. (2002) to investigate the possibility of the existence of heteromers containing these two receptors. Thus, co-localization of $\mathrm{A}_{2 \mathrm{~A}} \mathrm{R}$ and mGlu5 at the membrane level was demonstrated by confocal laser microscopy in co-transfected human embryonic kidney (HEK) 293 cells. In addition, western blotting has provided evidence for complexes containing $\mathrm{A}_{2 \mathrm{~A}} \mathrm{R}$ and mGlu5 in membrane preparations from both co-transfected HEK293 cells and rat striatal tissue (Ferre et al., 2002). Binding of the $\mathrm{A}_{2 \mathrm{~A}}$ receptor antagonist $\left[{ }^{125} \mathrm{I}\right] \mathrm{ZM} 241385$ in mouse striatum is reduced as a result of pretreatment with mGlu5 antagonist MTEP (Brown et al., 2011a), providing a neurochemical correlate for a possible allosteric interaction between these receptors. Potential for crosstalk also exists between the receptors' signal transduction pathways (Agnati et al., 2003), and there is functional evidence of a relationship between mGlu5 and $A_{2 A} R$ to this effect. Firstly, an apparent interdependence exists between the actions of $\mathrm{A}_{2 \mathrm{~A}} \mathrm{R}$ and mGlu5 in the phosphorylation of dopamine and cAMP-regulated phosphoprotein of 32,000 kDa (DARPP-32) at Thr-34 (Nishi et al., 2003). Thus, $A_{2 A} R$ antagonism attenuates the ability of mGlu5 activation to phosphorylate DARPP-32 at Thr-34 in mouse striatal slices and vice versa. In addition, co-activation of $m G l u 5$ and $A_{2 A} R$ synergistically increases phosphorylation of DARPP-32 at Thr-34, apparently via an extracellular signal-regulated kinase (ERK)1/2dependent mechanism involving increases in cAMP formation (Nishi et al., 2003). These findings are consistent with an ERK1/2dependent synergistic interaction between $\mathrm{A}_{2 \mathrm{~A}} \mathrm{R}$ and mGlu5 with respect to $c$-fos expression in HEK293 cells (Ferre et al., 2002). Collectively, these data have led some researchers in the field to suggest that the existence of this $\mathrm{A}_{2 \mathrm{~A}} \mathrm{R}-\mathrm{mGlu} 5$ heteromer may provide a point of temporal and spatial convergence of $G_{s}$ and $G_{q}$ signaling onto the MAPK cascade, thereby providing the capacity to influence striatal plasticity (Agnati et al., 2010a), thus raising the possibility of the involvement of this heteromer in plasticity resulting from repeated exposure to drugs of abuse. Of interest is the observation that both $\mathrm{A}_{2 \mathrm{~A}} \mathrm{R}$ and mGlu5 have been shown to play a role in corticostriatal plasticity (d'Alcantara et al., 2001; Sung et al., 2001).

In vivo microdialysis experiments have shown that perfusion with the $\mathrm{A}_{2 \mathrm{~A}} \mathrm{R}$ agonist 2-[4-(2-carboxy ethyl)phenethylamine-50$n$-ethylcarboxamidoadenosine (CGS21680) potentiates the facilitation of GABA release from striatopallidal neurons by the mGlu5 agonist (RS)-2-chloro-5-hydroxyphenylglycine (CHPG; Diaz-Cabiale et al., 2002). In addition, $A_{2 A} R$ and mGlu5 have been shown to interact synergistically to modulate glutamate release from corticostriatal afferents (Rodrigues et al., 2005). Submaximal concentrations of the $\mathrm{A}_{2 \mathrm{~A}} \mathrm{R}$ agonist CGS21680 and mGlu5 agonist CHPG have been shown to synergistically facilitate glutamate release, with the CGS21680-facilitated release prevented by
MPEP. Conversely, facilitation of glutamate release by CHPG is prevented by the $\mathrm{A}_{2 \mathrm{~A}} \mathrm{R}$ antagonist SCH58261 (Rodrigues et al., 2005). These results demonstrate that in addition to modulating striatal output, $\mathrm{mGlu} 5-\mathrm{A}_{2 \mathrm{~A}} \mathrm{R}$ interactions also play a role in regulating cortical input into the striatum, providing an additional avenue to influence striatal function and ultimately behavior.

Indeed, behavioral interactions between $\mathrm{A}_{2 \mathrm{~A}} \mathrm{R}$ and mGlu5 have been reported, particularly with respect to motor behaviors due to the strong interest in these receptors for their potential in the treatment of Parkinson's disease. For example, central coadministration of CGS21680 and CHPG has been found to reduce the motor activity induced by phencyclidine at doses that have no effect alone (Ferre et al., 2002). Furthermore, in both normal and reserpinized mice, locomotion is enhanced in a synergistic manner with combined treatment of MPEP and the $\mathrm{A}_{2 \mathrm{~A}} \mathrm{R}$ antagonist KW-6002 (Kachroo et al., 2005). Similarly, akinetic symptoms of 6hydroxydopamine-lesioned rats are improved with combinations of sub-threshold doses of mGlu5 and $\mathrm{A}_{2 \mathrm{~A}} \mathrm{R}$ antagonists (Coccurello et al., 2004). More recently, evidence has been forthcoming which suggests the $A_{2 A} R-m G l u 5$ interaction is also relevant to reward and drug-seeking behavior (discussed in subsequent section).

Recently, co-immunoprecipitation experiments in native striatal tissue provided evidence for the existence of a higher-order oligomeric complex containing mGlu5, $\mathrm{D}_{2} \mathrm{R}$, and $\mathrm{A}_{2 \mathrm{~A}} \mathrm{R}$, localized to the dendritic spines of striatopallidal neurons (Cabello et al., 2009). These results supported earlier experiments which demonstrated functional interactions between these three GPCRs. Early studies reported synergy between $\mathrm{A}_{2 \mathrm{~A}} \mathrm{R}$ and mGlu5 in reducing dopamine $\mathrm{D}_{2} \mathrm{R}$-mediated behaviors such as phencyclidineinduced hyperactivity (Ferre et al., 2002) and dopamine signaling through DARPP-32 (Nishi et al., 2003). In rat striatal membranes, the $\mathrm{A}_{2 \mathrm{~A}} \mathrm{R}$ agonist CGS21680 potentiates the effect of mGlu5 agonist CHPG in reducing the affinity of $\mathrm{D}_{2}$ receptors for the agonist (Popoli et al., 2001). It therefore appears that $\mathrm{A}_{2 \mathrm{~A}} \mathrm{R}$ and mGlu5 work together to antagonize $\mathrm{D}_{2} \mathrm{R}$-mediated signaling in the striatum. Under baseline conditions, there would be strong tonic activation of $\mathrm{D}_{2} \mathrm{R}$ in the striatum which would impair the ability of the $\mathrm{A}_{2 \mathrm{~A}} \mathrm{R}$ to signal through adenylate cyclase/cAMP/PKA. Co-stimulation of mGlu5 thus allows $\mathrm{A}_{2 \mathrm{~A}} \mathrm{R}$ stimulation to override the inhibitory tone imposed by endogenous dopamine acting at $\mathrm{D}_{2}$ receptors (Ferre et al., 2002). This is supported by behavioral data as activation of $\mathrm{A}_{2 \mathrm{~A}} \mathrm{R}$ and mGlu5 causes attenuation of $\mathrm{D}_{2} \mathrm{R}$ agonist quinpirole-induced contralateral turning in 6-hydroxydopamine-lesioned rats (Popoli et al., 2001).

Studies performed in heterologous expression systems utilizing a range of biophysical and biochemical techniques have provided evidence for the existence of this unique "biochemical fingerprint" as a result of the specific receptor interaction (Agnati et al., 2010b). For example, in the case of $A_{2 A} R-D_{2} R$ and mGlu5- $\mathrm{D}_{2} \mathrm{R}$ complexes, heteromerization appears to result in an antagonistic allosteric effect where $\mathrm{A}_{2 \mathrm{~A}} \mathrm{R}$ and mGlu5 agonists, respectively, reduced the affinity of the $\mathrm{D}_{2}$ agonist-binding sites (Ferre et al., 1999; Popoli et al., 2001; Torvinen et al., 2004). In the case of the mGlu5- $\mathrm{A}_{2 \mathrm{~A}} \mathrm{R}$ heteromer however, co-stimulation of both receptors appears to result in a synergistic effect on downstream signaling (Ferre et al., 2002). mGlu5 and $\mathrm{A}_{2 \mathrm{~A}} \mathrm{R}$ antagonists 
have been reported to reduce alcohol-seeking behavior in rats; interestingly, co-administration of antagonists for these receptors has a synergistic effect in rats, supporting the existence and functional importance of the heteromer in addiction-associated behaviors (Adams et al., 2008). We have consequently suggested exploiting the limited overlapping expression of mGlu5 and $\mathrm{A}_{2 \mathrm{~A}} \mathrm{R}$ for developing potential therapies, which target a sub-population of receptors (Bird and Lawrence, 2009b). By developing putative heteromer-selective drugs, the problematic issue of modulating the widely distributed and multifunctional mGlu5 receptor could be potentially overcome.

\section{CONCEPTS OF "RECEPTOR MOSAIC" AND "HUB RECEPTOR"}

The idea of "receptor mosaics" suggests that proteins can form even more complex and dynamic networks, with respect to time and protein make up, which has the potential to make significant contributions to the diversity and specificity of GPCR signaling, particularly in neuropharmacology, where a few key receptors have been implicated in multiple neurological and psychiatric disorders (Agnati et al., 2009). Agnati and Fuxe first introduced this concept of receptor mosaics in 1982 in the context of learning and memory (Agnati et al., 1982). As suggested by Fuxe et al. (2008) this "receptor mosaic" term not only allows the interactions between the different receptors (stoichiometry) to be taken into account but also their spatial organization (topography) and their order of activation. It has been proposed that by changing the order of activation, functionally distinct receptor mosaics can transduce signals resulting in distinct biological responses. This may be of particular importance for neuropharmacology where different agonist concentrations direct activation of one receptor mosaic activity over another. This can be exemplified by considering a receptor mosaic which consists of three different receptors; A, B, and C and therefore can potentially result in six functional outcomes (Fuxe et al., 2008). For reviews on receptor mosaics and their implications see (Fuxe et al., 2007, 2008; Agnati et al., 2010a,b; Fuxe and Kenakin, 2010).

Furthermore, it has been suggested that receptor mosaics are composed of at least one so called "hub receptor" - a receptor, capable of forming multiple connections, which can result in differing pharmacology depending on these connections (Agnati et al., 2010a). Hub receptors have been classified into three distinct groups; passive hubs which allow the flow of information; intelligent hubs modify the information as it flows through; and switching hubs, which direct the information to the correct destination (Agnati et al., 2010a). It has been postulated that the $\mathrm{D}_{2}$ receptor acts as a "hub receptor," with evidence in the literature for its interaction with the $\mathrm{A}_{2 \mathrm{~A}}$ and mGlu5 receptors (Cabello et al., 2009) as well as $A_{2 A}$ and $C_{1}$ (Agnati et al., 2009) to form trimeric receptor mosaics. Cabello et al. (2009) have reported the existence of these receptor mosaics in the perisynaptic and extrasynaptic parts of the neuronal plasma membrane. As mentioned above, it is thought that this trimeric receptor mosaic plays a role on the extrasynaptic striatopallidal GABA neurons and possibly in corticostriatal glutamate terminals. As only a small population of these receptors are expected to form complexes at any given time or location, this may allow even more selectivity when designing drug therapies. Modulation of specific interactions and pathways has the potential to reduce side effects, of paramount importance in the treatment of neurological disorders, where lack of specificity could impair vital brain function.

\section{mGIU5 RECEPTOR FUNCTIONAL INTERACTIONS: EVIDENCE FOR A ROLE IN ADDICTION}

Given the specific localization of apparent mGlu5 receptor complexes in the striatum, as well as the established involvement of plasticity in glutamatergic corticostriatal neurons in the reinstatement of drug-seeking in animal models of relapse (Kalivas, 2009), one may hypothesize that interactions between mGlu5 and $\mathrm{A}_{2 \mathrm{~A}} \mathrm{R}$ have the potential to regulate drug-seeking or the conditioned effects of drugs of abuse. Indeed, two recent studies have provided evidence as such. Firstly, as mentioned previously, functional interactions between mGlu5 and $\mathrm{A}_{2 \mathrm{~A}}$ receptors were shown to regulate operant self-administration of alcohol and cue-induced reinstatement of alcohol-seeking (Adams et al., 2008). Sub-threshold doses of SCH58261, a selective $\mathrm{A}_{2 \mathrm{~A}}$ receptor antagonist and MTEP, an mGlu5 antagonist, were administrated in combination and were found to act synergistically to decrease operant self-administration of alcohol and cue-induced reinstatement of alcohol-seeking (Adams et al., 2008). These doses had no effect when given alone. In addition, no support was found for interactions between adenosine $A_{1}$ and $A_{2 A} R$, or $A_{1}$ and mGlu5, suggesting this reduction in alcohol self-administration and alcohol-seeking behavior was specific to a functional interaction between $\mathrm{A}_{2 \mathrm{~A}}$ and mGlu5 receptors (Adams et al., 2008, 2010).

It is now recognized that reinstatement of drug-seeking involves corticostriatal glutamatergic input into the striatum (Kalivas and McFarland, 2003; Kalivas et al., 2005). Prior co-administration of SCH58261 and MTEP may have prevented cue-elicited release of glutamate in this context, thus preventing drug-seeking behavior. This fits nicely with the role discussed earlier for $A_{2 A} R$ and $\mathrm{mGlu} 5$ in regulating glutamate release from corticostriatal afferent neurons (Rodrigues et al., 2005). In rats, stimulation of corticostriatal afferents has been shown to result in phosphorylation of ERK which can be prevented by $\mathrm{A}_{2 \mathrm{~A}} \mathrm{R}$ antagonism (Quiroz et al., 2009), thus providing one possible mechanism for this observation. Though no direct evidence exists as yet, it is also possible that specialized receptor complexes containing multiple GPCRs are involved in this behavior, and that plasticity may occur with repeated drug use which alters the arrangement of or signaling through this receptor complex. Though the exact nature of the interactions between mGlu5 and $\mathrm{A}_{2 \mathrm{~A}}$ receptors are yet to be determined and involvement of potential "hub" receptors such as the $\mathrm{D}_{2} \mathrm{R}$ remains to be explored, it is clear that a biologically relevant functional interaction between these two GPCRs can act to regulate drug-seeking behavior providing evidence of the therapeutic potential of targeting mGlu5 and $\mathrm{A}_{2 \mathrm{~A}} \mathrm{R}$ in combination.

A similar functional interaction was found between mGlu5 and $\mathrm{A}_{2 \mathrm{~A}} \mathrm{R}$ in relation to cocaine-driven behaviors (Brown et al., 2011a) providing further evidence of the potential of this possible drug target. Despite preventing a conditioned place preference to cocaine in wildtype mice, MTEP treatment had no impact on the ability of $\mathrm{A}_{2 \mathrm{~A}} \mathrm{R}$ knockout mice to develop a robust conditioned place preference to cocaine, suggesting a functional $A_{2 A} R$ is required for mGlu5 to regulate the acquisition of incentive 
properties in a cocaine-paired context. This finding was mirrored by conditioned hyperactivity data, whereby MTEP completely prevented conditioned hyperactivity in wildtype mice but had no impact in $\mathrm{A}_{2 \mathrm{~A}} \mathrm{R}$ knockout mice. In contrast, MTEP was able to block the locomotor-activating properties of cocaine in both wildtype and $\mathrm{A}_{2 \mathrm{~A}} \mathrm{R}$ knockout mice. It should be noted that conditioned hyperactivity was assessed during the test session when all mice were in a drug-free state. Conditioned hyperactivity therefore, as with conditioned place preference, is driven purely by contextual associations and is hence likely to be underpinned by similar neural processes. Hence, it appears that a functional $\mathrm{A}_{2 \mathrm{~A}} \mathrm{R}$ may be critical for the actions of MTEP in regulating both the conditioned reinforcing and conditioned locomotor-activating properties of cocaine, but not the direct locomotor effects of acute cocaine. These data are in line with recent evidence supporting a role for mGlu5 in incentive learning processes (Novak et al., 2010; O'Connor et al., 2010).

As the ventral striatum is a key component of the neural circuitry underlying Pavlovian conditioning (Robbins et al., 2008), it seems probable that it is a likely site of action for this interaction. However it should be noted that both $\mathrm{A}_{2 \mathrm{~A}} \mathrm{R}$ and mGlu5 were recently shown to be co-localized in the hippocampus (Tebano et al., 2005) and have been implicated in learning and memory processes (Simonyi et al., 2005; Gimenez-Llort et al., 2007). For example, $\mathrm{A}_{2 \mathrm{~A}} \mathrm{R}$ have been shown to play a key role in hippocampaldependent associative learning in a classical eye-blinking paradigm (Fontinha et al., 2009) and mGlu5 is implicated in spatial memory ( $\mathrm{Lu}$ et al., 1997). Given that conditioned place preference is a paradigm that relies on contextual learning, functional interactions between mGlu5 and $\mathrm{A}_{2 \mathrm{~A}} \mathrm{R}$ in the hippocampus cannot be ruled out.

\section{CONCLUSION}

This review has outlined the evidence supporting a role for functional interactions between mGlu5 and other GPCRs, particularly the adenosine $\mathrm{A}_{2 \mathrm{~A}} \mathrm{R}$, in reward, drug-seeking, and drug-induced plasticity. Though much evidence now exists describing the individual contribution that mGlu5, $\mathrm{D}_{2} \mathrm{R}$, and $\mathrm{A}_{2 \mathrm{~A}} \mathrm{R}$ make to various facets of addictive behavior, only a small number of studies thus

\section{REFERENCES}

Adams, C. L., Cowen, M. S., Short, J. L., and Lawrence, A. J. (2008). Combined antagonism of glutamate mGlu5 and adenosine A2A receptors interact to regulate alcohol-seeking in rats. Int. J. Neuropsychopharmacol. 11, 229-241.

Adams, C. L., Short, J. L., and Lawrence, A. J. (2010). Cue-conditioned alcohol seeking in rats following abstinence: involvement of mGlu5 receptors. Br. J. Pharmacol. 159, 534-542.

Agnati, L. F., Ferre, S., Lluis, C., Franco, R., and Fuxe, K. (2003). Molecular mechanisms and therapeutical implications of intramembrane receptor/receptor interactions among heptahelical receptors with examples from the striatopallidal

far have investigated interactions between mGlu5 and these other GPCRs in this context. Initial studies suggest that mGlu5 receptor interactions may play a role in the rewarding and incentive motivational properties of drugs of abuse, drug-seeking, as well as the conditioned effects of drugs of abuse. This is consistent with the substantial influence that interactions between mGlu5 and these other receptors appear to have on striatal function, regulating both GABAergic output of striatopallidal neurons and glutamatergic input from corticostriatal afferents. The specific nature of these interactions has not yet been determined and though it is possible that striatal mGlu5-containing complexes are responsible for regulating drug-seeking, future studies should aim to determine whether or not this is the case as well as determine the exact site of action as mGlu5 has recently been shown to co-localize with $\mathrm{A}_{2 \mathrm{~A}} \mathrm{R}$ in the hippocampus (Tebano et al., 2005). In addition, the role of the $\mathrm{D}_{2}$ receptor as a potential "hub" receptor should be investigated in this context. Furthermore, in order to overcome the problematic issue of therapeutically modulating the widely distributed and multifunctional mGlu5, the limited overlapping expression of mGlu5, $\mathrm{D}_{2}$, and $\mathrm{A}_{2 \mathrm{~A}} \mathrm{R}$ may be exploited when designing drug therapies aimed at exhibiting little or no off-target effects. On the other hand, if such "complexes" do not prove to be relevant in vivo in humans, exploitation of specific functional interactions that have biological significance (e.g., downstream mGlu5- $\mathrm{A}_{2 \mathrm{~A}}$ receptor functional interactions which are well-established) could provide an equally attractive proposition. Indeed, the therapeutic targeting of receptor mosaics/functional interactions in a tissue specific or temporal manner (for example, a sub-population of receptors in a "pathological state") has the potential to reduce detrimental side effects that may otherwise impair vital brain function.

\section{ACKNOWLEDGMENTS}

These studies were supported by a project grant 566736 from the NHMRC (Australia) of which Andrew J. Lawrence is a Principal Fellow and Robyn M. Brown is an Early Career Research Fellow. Kevin D. G. Pfleger is an Australian Research Council Future Fellow (FT100100271). We also acknowledge the Victorian Government's Operational Infrastructure Support Program.

$\mathrm{CB}(1)$, and metabotropic glutamate $\mathrm{mGlu}(5)$ receptors. J. Recept. Signal Transduct. Res. 30, 355-369.

Agnati, L. F., Guidolin, D., Vilardaga, J. P., Ciruela, F., and Fuxe, K. (2010b). On the expanding terminology in the GPCR field: the meaning of receptor mosaics and receptor heteromers. J. Recept. Signal Transduct. Res. 30, 287-303.

Albizu, L., Moreno, J. L., GonzalezMaeso, J., and Sealfon, S. C. (2010). Heteromerization of $\mathrm{G}$ proteincoupled receptors: relevance to neurological disorders and neurotherapeutics. CNS Neurol. Disord. Drug Targets 9, 636-650.

Arolfo, M. P., Yao, L., Gordon, A. S., Diamond, I., and Janak, P. H. (2004). Ethanol operant self-administration in rats is regulated by adenosine A2 receptors. Alcohol. Clin. Exp. Res. 28, 1308-1316.

Attucci, S., Carla, V., Mannaioni, G., and Moroni, F. (2001). Activation of type 5 metabotropic glutamate receptors enhances NMDA responses in mice cortical wedges. Br. J. Pharmacol. 132, 799-806.

Backstrom, P., Bachteler, D., Koch, S., Hyytia, P., and Spanagel, R. (2004). mGluR5 antagonist MPEP reduces ethanol-seeking and relapse behavior. Neuropsychopharmacology 29, 921-928.

Backstrom, P., and Hyytia, P. (2006). Ionotropic and metabotropic glutamate receptor antagonism attenuates cue-induced cocaine seeking. Neuropsychopharmacology 31, 778-786. 
Bespalov, A. Y., Dravolina, O. A., Sukhanov, I., Zakharova, E., Blokhina, E., Zvartau, E., Danysz, W., Van Heeke, G., and Markou, A. (2005). Metabotropic glutamate receptor (mGluR5) antagonist MPEP attenuated cue- and schedule-induced reinstatement of nicotine self-administration behavior in rats. Neuropharmacology 49(Suppl. 1), 167-178.

Bird, M. K., Kirchhoff, J., Djouma, E., and Lawrence, A. J. (2008). Metabotropic glutamate 5 receptors regulate sensitivity to ethanol in mice. Int. J. Neuropsychopharmacol. 11, 765-774.

Bird, M. K., and Lawrence, A. J. (2009a). Group I metabotropic glutamate receptors: involvement in drugseeking and drug-induced plasticity. Curr. Mol. Pharmacol. 2, 83-94.

Bird, M. K., and Lawrence, A. J. (2009b). The promiscuous mGlu5 receptora range of partners for therapeutic possibilities? Trends Pharmacol. Sci. 30, 617-623.

Bird, M. K., Reid, C. A., Chen, F., Tan, H. O., Petrou, S., and Lawrence, A. J. (2010). Cocaine-mediated synaptic potentiation is absent in VTA neurons from mGlu5-deficient mice. Int. J. Neuropsychopharmacol. 13, 133-141.

Bonci, A., and Hopf, F. W. (2005). The dopamine D2 receptor: new surprises from an old friend. Neuron 47, 335-338.

Brown, R. M., Duncan, J. R., Stagnitti, M. R., Ledent, C., and Lawrence, A. J. (2011a). mGlu5 and adenosine $\mathrm{A} 2 \mathrm{~A}$ receptor interactions regulate the conditioned effects of cocaine. Int. J. Neuropsychopharmacol. 1-7. doi:10.1017/S146114571100126X. [Epub ahead of print].

Brown, R. M., Stagnitti, M. R., Duncan, J. R., and Lawrence, A. J. (2011b). The mGlu5 receptor antagonist MTEP attenuates opiate self-administration and cue-induced opiate-seeking behaviour in mice. Drug Alcohol Depend. doi:10.1016/j.drugalcdep.2011.11.002. [Epub ahead of print].

Brown, R. M., and Short, J. L. (2008). Adenosine A2A receptors and their role in drug addiction. J. Pharm. Pharmacol. 60, 1409-1430.

Brown, R. M., Short, J. L., Cowen, M. S., Ledent, C., and Lawrence, A. J. (2009). A differential role for the adenosine A2A receptor in opiate reinforcement vs opiate-seeking behavior. Neuropsychopharmacology 34, 844-856.

Cabello, N., Gandia, J., Bertarelli, D. C., Watanabe, M., Lluis, C., Franco,
R., Ferre, S., Lujan, R., and Ciruela, F. (2009). Metabotropic glutamate type 5 , dopamine $\mathrm{D} 2$ and adenosine A2A receptors form higher-order oligomers in living cells. J. Neurochem. 109, 1497-1507.

Canals, M., Marcellino, D., Fanelli, F., Ciruela, F., De Benedetti, P., Goldberg, S. R., Neve, K., Fuxe, K., Agnati, L. F., Woods, A. S., Ferre, S., Lluis, C., Bouvier, M., and Franco, R. (2003). Adenosine A2A-dopamine D2 receptor-receptor heteromerization: qualitative and quantitative assessment by fluorescence and bioluminescence energy transfer. J. Biol. Chem. 278, 46741-46749.

Chiamulera, C., Epping-Jordan, M. P., Zocchi, A., Marcon, C., Cottiny, C., Tacconi, S., Corsi, M., Orzi, F., and Conquet, F. (2001). Reinforcing and locomotor stimulant effects of cocaine are absent in mGluR5 null mutant mice. Nat. Neurosci. 4, 873-874.

Ciruela, F., Casado, V., Rodrigues, R. J., Lujan, R., Burgueno, J., Canals, M., Borycz, J., Rebola, N., Goldberg, S. R., Mallol, J., Cortes, A., Canela, E. I., Lopez-Gimenez, J. F., Milligan, G., Lluis, C., Cunha, R. A., Ferre, S., and Franco, R. (2006). Presynaptic control of striatal glutamatergic neurotransmission by adenosine A1-A2A receptor heteromers. J. Neurosci. 26, 2080-2087.

Cleva, R. M., Hicks, M. P., Gass, J. T., Wischerath, K. C., Plasters, E. T., Widholm, J. J., and Olive, M. F. (2011). mGluR5 positive allosteric modulation enhances extinction learning following cocaine selfadministration. Behav. Neurosci. 125, 10-19.

Cleva, R. M., and Olive, M. F. (2011). Positive allosteric modulators of type 5 metabotropic glutamate receptors (mGluR5) and their therapeutic potential for the treatment of CNS disorders. Molecules 16, 2097-2106.

Coccurello, R., Breysse, N., and Amalric, M. (2004). Simultaneous blockade of adenosine $\mathrm{A} 2 \mathrm{~A}$ and metabotropic glutamate mGlu5 receptors increase their efficacy in reversing Parkinsonian deficits in rats. Neuropsychopharmacology 29, 1451-1461.

Collins, D. J., and Lapsley, H. M. (2002). Counting the Cost: Estimates of the Social Costs of Drug Abuse in Australia in 1998-9. Canberra: Commonwealth Department of Health and Aged Care.

Cowen, M. S., Djouma, E., and Lawrence, A. J. (2005). The metabotropic glutamate 5 receptor antagonist 3-[(2-methyl-1,3thiazol-4-yl)ethynyl]-pyridine reduces ethanol self-administration in multiple strains of alcoholpreferring rats and regulates olfactory glutamatergic systems. $J$. Pharmacol. Exp. Ther. 315, 590-600.

Cowen, M. S., Krstew, E., and Lawrence, A. J. (2007). Assessing appetitive and consummatory phases of ethanol self-administration in C57BL/6J mice under operant conditions: regulation by mGlu5 receptor antagonism. Psychopharmacology (Berl.) 190, 21-29.

d'Alcantara, P., Ledent, C., Swillens, S., and Schiffmann, S. N. (2001). Inactivation of adenosine $\mathrm{A} 2 \mathrm{~A}$ receptor impairs long term potentiation in the accumbens nucleus without altering basal synaptic transmission. Neuroscience 107, 455-464.

Dalrymple, M. B., Pfleger, K. D., and Eidne, K. A. (2008). G proteincoupled receptor dimers: functional consequences, disease states and drug targets. Pharmacol. Ther. 118, 359-371.

Dejong, W. (1994). Relapse prevention: an emerging technology for promoting long-term drug abstinence. Int. J. Addict. 29, 681-705.

Dhami, G. K., and Ferguson, S. S. (2006). Regulation of metabotropic glutamate receptor signaling, desensitization and endocytosis. Pharmacol. Ther. 111, 260-271.

Diaz-Cabiale, Z., Vivo, M., Del Arco, A., O'Connor, W. T., Harte, M. K., Muller, C. E., Martinez, E., Popoli, P., Fuxe, K., and Ferre, S. (2002). Metabotropic glutamate mGlu5 receptor-mediated modulation of the ventral striopallidal GABA pathway in rats. Interactions with adenosine $\mathrm{A}(2 \mathrm{~A})$ and dopamine $\mathrm{D}(2)$ receptors. Neurosci. Lett. 324, 154-158.

Fastbom, J., Pazos, A., and Palacios, J. M. (1987). The distribution of adenosine Al receptors and $5^{\prime}$ nucleotidase in the brain of some commonly used experimental animals. Neuroscience 22, 813-826.

Ferre, S., Agnati, L. F., Ciruela, F., Lluis, C., Woods, A. S., Fuxe, K., and Franco, R. (2007a). Neurotransmitter receptor heteromers and their integrative role in "local modules": the striatal spine module. Brain Res. Rev. 55, 55-67.

Ferre, S., Ciruela, F., Woods, A. S., Lluis, C., and Franco, R. (2007b). Functional relevance of neurotransmitter receptor heteromers in the central nervous system. Trends Neurosci. 30 , 440-446.
Ferre, S., Diamond, I., Goldberg, S. R., Yao, L., Hourani, S. M., Huang, Z. L., Urade, Y., and Kitchen, I. (2007c). Adenosine A2A receptors in ventral striatum, hypothalamus and nociceptive circuitry implications for drug addiction, sleep and pain. Prog. Neurobiol. 83, 332-347.

Ferre, S., Baler, R., Bouvier, M., Caron, M. G., Devi, L. A., Durroux, T., Fuxe, K., George, S. R., Javitch, J. A., Lohse, M. J., Mackie, K., Milligan, G., Pfleger, K. D., Pin, J. P., Volkow, N. D., Waldhoer, M., Woods, A. S., and Franco, R. (2009). Building a new conceptual framework for receptor heteromers. Nat. Chem. Biol. 5, 131-134.

Ferre, S., Ciruela, F., Canals, M., Marcellino, D., Burgueno, J., Casado, V. Hillion, J., Torvinen, M., Fanelli, F., Benedetti Pd, P., Goldberg, S. R. Bouvier, M., Fuxe, K., Agnati, L. F., Lluis, C., Franco, R., and Woods, A. (2004). Adenosine A2A-dopamine D2 receptor-receptor heteromers. Targets for neuro-psychiatric disorders. Parkinsonism Relat. Disord. 10 , 265-271.

Ferre, S., Karcz-Kubicha, M., Hope, B. T., Popoli, P., Burgueno, J., Gutierrez, M. A., Casado, V., Fuxe, K., Goldberg, S. R., Lluis, C., Franco, R., and Ciruela, F. (2002). Synergistic interaction between adenosine A2A and glutamate mGlu5 receptors: implications for striatal neuronal function. Proc. Natl. Acad. Sci. U.S.A. 99, 11940-11945.

Ferre, S., O'Connor, W. T., Snaprud, P., Ungerstedt, U., and Fuxe, K. (1994). Antagonistic interaction between adenosine $\mathrm{A} 2 \mathrm{~A}$ receptors and dopamine D2 receptors in the ventral striopallidal system. Implications for the treatment of schizophrenia. Neuroscience 63, 765-773.

Ferre, S., Popoli, P., Rimondini, R., Reggio, R., Kehr, J., and Fuxe, K. (1999). Adenosine A2A and group I metabotropic glutamate receptors synergistically modulate the binding characteristics of dopamine D2 receptors in the rat striatum. Neuropharmacology 38, 129-140.

Fink, J. S., Weaver, D. R., Rivkees, S. A., Peterfreund, R. A., Pollack, A. E., Adler, E. M., and Reppert, S. M. (1992). Molecular cloning of the rat A2 adenosine receptor: selective coexpression with D2 dopamine receptors in rat striatum. Mol. Brain Res. 14, 186-195.

Fontinha, B. M., Delgado-Garcis, J. M., Madronal, N., Ribeiro, J. A., Sebastiao, A. M., and Gruart, 
A. (2009). Adenosine A2A receptor modulation of hippocampal CA3-CA1 synapse plasticity during associative learning in behaving mice. Neuropsychopharmacology 34 , 1865-1874.

Fredholm, B. B., Abbracchio, M. P., Burnstock, G., Daly, J. W., Harden, T. K., Jacobson, K. A., Leff, P., and Williams, M. (1994). VI. Nomenclature and classification of purinoceptors. Pharmacol. Rev. 46, 143-156.

Fredholm, B. B., Ap, I. J., Jacobson, K. A., Klotz, K. N., and Linden, J. (2001a). International Union of Pharmacology. XXV. Nomenclature and classification of adenosine receptors. Pharmacol. Rev. 53, 527-552.

Fredholm, B. B., Irenius, E., Kull, B., and Schulte, G. (2001b). Comparison of the potency of adenosine as an agonist at human adenosine receptors expressed in Chinese hamster ovary cells. Biochem. Pharmacol. 61, 443-448.

Fredholm, B. B., and Svenningsson, P. (2003). Adenosine-dopamine interactions: development of a concept and some comments on therapeutic possibilities. Neurology 61, S5-S9.

Fuxe, K., Agnati, L. F., Jacobsen, K., Hillion, J., Canals, M., Torvinen, M., Tinner-Staines, B., Staines, W., Rosin, D., Terasmaa, A., Popoli, P., Leo, G., Vergoni, V., Lluis, C., Ciruela, F., Franco, R., and Ferre, S. (2003). Receptor heteromerization in adenosine A2A receptor signaling: relevance for striatal function and Parkinson's disease. Neurology 61, S19-S23.

Fuxe, K., Canals, M., Torvinen, M., Marcellino, D., Terasmaa, A., Genedani, S., Leo, G., Guidolin, D., DiazCabiale, Z., Rivera, A., Lundstrom, L., Langel, U., Narvaez, J., Tanganelli, S., Lluis, C., Ferre, S., Woods, A., Franco, R., and Agnati, L. F. (2007). Intramembrane receptorreceptor interactions: a novel principle in molecular medicine. J. Neural Transm. 114, 49-75.

Fuxe, K., and Kenakin, T. (2010). The changing world of $\mathrm{G}$ proteincoupled receptors. J. Recept. Signal Transduct. Res. 30, 271.

Fuxe, K., Marcellino, D., BorrotoEscuela, D. O., Guescini, M., Fernandez-Duenas, V., Tanganelli, S., Rivera, A., Ciruela, F., and Agnati, L. F. (2010). Adenosine-dopamine interactions in the pathophysiology and treatment of CNS disorders. CNS Neurosci. Ther. 16, e18-e42.

Fuxe, K., Marcellino, D., Rivera, A., Diaz-Cabiale, Z., Filip, M., Gago, B. Roberts, D. C., Langel, U., Genedani,
S., Ferraro, L., De La Calle, A., Narvaez, J., Tanganelli, S., Woods, A., and Agnati, L. F. (2008). Receptorreceptor interactions within receptor mosaics. Impact on neuropsychopharmacology. Brain Res. Rev. $58,415-452$.

Gass, J. T., and Olive, M. F. (2009). Positive allosteric modulation of mGluR5 receptors facilitates extinction of a cocaine contextual memory. Biol. Psychiatry 65, 717-720.

Gass, J. T., Osborne, M. P., Watson, N. L., Brown, J. L., and Olive, M. F. (2009). mGluR5 antagonism attenuates methamphetamine reinforcement and prevents reinstatement of methamphetamine-seeking behavior in rats. Neuropsychopharmacology 34, 820-833.

Gerfen, C. R. (1992). The neostriatal mosaic: multiple levels of compartmental organization. Trends Neurosci. 15, 133-139.

Gimenez-Llort, L., Schiffmann, S. N., Shmidt, T., Canela, L., Camon, L., Wassholm, M., Canals, M., Terasmaa, A., Fernandez-Teruel, A., Tobena, A., Popova, E., Ferre, S., Agnati, L., Ciruela, F., Martinez, E., Scheel-Kruger, J., Lluis, C., Franco, R., Fuxe, K., and Bader, M. (2007). Working memory deficits in transgenic rats overexpressing human adenosine $\mathrm{A} 2 \mathrm{~A}$ receptors in the brain. Neurobiol. Learn. Mem. 87, 42-56.

Gossop, M., Green, L., Phillips, G., and Bradley, B. (1989). Lapse, relapse and survival among opiate addicts after treatment. A prospective follow-up study. Br. J. Psychiatry 154, 348-353.

Hettinger, B. D., Lee, A., Linden, J., and Rosin, D. L. (2001). Ultrastructural localization of adenosine A2A receptors suggests multiple cellular sites for modulation of GABAergic neurons in rat striatum. J. Comp. Neurol. $431,331-346$.

Jupp, B., and Lawrence, A. J. (2009). New horizons for therapeutics in drug and alcohol abuse. Pharmacol. Ther. $125,138-168$.

Kachroo, A., Orlando, L. R., Grandy, D. K., Chen, J. F., Young, A. B., and Schwarzschild, M. A. (2005). Interactions between metabotropic glutamate 5 and adenosine $\mathrm{A}(2 \mathrm{~A})$ receptors in normal and parkinsonian mice. J. Neurosci. 25, 10414-10419.

Kalivas, P. W. (2009). The glutamate homeostasis hypothesis of addiction. Nat. Rev. Neurosci. 10, 561-572.

Kalivas, P. W., and McFarland, K. (2003). Brain circuitry and the reinstatement of cocaine-seeking behavior. Psychopharmacology (Berl.) 168, $44-56$.
Kalivas, P. W., Volkow, N., and Seamans, J. (2005). Unmanageable motivation in addiction: a pathology in prefrontal-accumbens glutamate transmission. Neuron 45, 647-650.

Kennedy, M. B. (2000). Signalprocessing machines at the postsynaptic density. Science 290, 750-754

Kenny, P. J., Paterson, N. E., Boutrel, B., Semenova, S., Harrison, A. A. Gasparini, F., Koob, G. F., Skoubis, P. D., and Markou, A. (2003). Metabotropic glutamate 5 receptor antagonist MPEP decreased nicotine and cocaine self-administration but not nicotine and cocaine-induced facilitation of brain reward function in rats. Ann. N. Y. Acad. Sci. 1003 415-418.

Keywood, C., Wakefield, M., and Tack, J. (2009). A proof-of-concept study evaluating the effect of ADX10059, a metabotropic glutamate receptor5 negative allosteric modulator, on acid exposure and symptoms in gastro-oesophageal reflux disease. Gut 58, 1192-1199.

Kreitzer, A. C., and Malenka, R. C. (2008). Striatal plasticity and basal ganglia circuit function. Neuron 60 , 543-554.

Le Moine, C., and Bloch, B. (1995). D1 and D2 dopamine receptor gene expression in the rat striatum: sensitive cRNA probes demonstrate prominent segregation of D1 and D2 mRNAs in distinct neuronal populations of the dorsal and ventral striatum. J. Comp. Neurol. 355, 418-426.

Lindemann, L., Jaeschke, G., Michalon, A., Vieira, E., Honer, M., Spooren, W., Porter, R., Hartung, T., Kolczewski, S., Buttelmann, B., Flament, C., Diener, C., Fischer, C. Gatti, S., Prinssen, E. P., Parrott, N., Hoffmann, G., and Wettstein, J. G. (2011). CTEP: a novel, potent, long-acting, and orally bioavailable metabotropic glutamate receptor 5 inhibitor. J. Pharmacol. Exp. Ther. $339,474-486$

Lindsley, C. W., Wisnoski, D. D., Leister, W. H., O'brien J, A., Lemaire, W., Williams, D. L. Jr., Burno, M. Sur, C., Kinney, G. G., Pettibone, D. J., Tiller, P. R., Smith, S., Duggan, M. E., Hartman, G. D., Conn P. J., and Huff, J. R. (2004). Discovery of positive allosteric modulators for the metabotropic glutamate receptor subtype 5 from a series of N-(1,3-diphenyl-1H- pyrazol-5yl)benzamides that potentiate receptor function in vivo. J. Med. Chem. 47, 5825-5828.

Liu, F., Grauer, S., Kelley, C., Navarra, R., Graf, R., Zhang, G., Atkinson,
P. J., Popiolek, M., Wantuch, C., Khawaja, X., Smith, D., Olsen, M., Kouranova, E., Lai, M., Pruthi, F., Pulicicchio, C., Day, M., Gilbert, A., Pausch, M. H., Brandon, N. J., Beyer, C. E., Comery, T. A., Logue, S., Rosenzweig-Lipson, S., and Marquis, K. L. (2008). ADX47273 [S-(4-fluoro-phenyl)-\{3-[3-(4fluoro-phenyl)-[1,2,4]-oxadiazol5-yl]-piper idin-1-yl\}-methanone]: a novel metabotropic glutamate receptor 5-selective positive allosteric modulator with preclinical antipsychotic-like and procognitive activities. J. Pharmacol. Exp. Ther. 327, 827-839.

Lu, Y. M., Jia, Z., Janus, C., Henderson, J. T., Gerlai, R., Wojtowicz, J. M., and Roder, J. C. (1997). Mice lacking metabotropic glutamate receptor 5 show impaired learning and reduced CA1 long-term potentiation (LTP) but normal CA3 LTP. J. Neurosci. 17, 5196-5205.

Missale, C., Nash, S. R., Robinson, S. W., Jaber, M., and Caron, M. G. (1998). Dopamine receptors: from structure to function. Physiol. Rev. 78, 189-225.

Mustafa, S., Ayoub, M. A., and Pfleger, K. D. G. (2010). Uncovering GPCR heteromer-biased ligands. Drug Discov. Today Technol. 7, e77-e85.

Naisbitt, S., Kim, E., Tu, J. C., Xiao, B., Sala, C., Valtschanoff, J., Weinberg, R. J., Worley, P. F., and Sheng, M. (1999). Shank, a novel family of postsynaptic density proteins that binds to the NMDA receptor/PSD95/GKAP complex and cortactin. Neuron 23, 569-582.

Nishi, A., Liu, F., Matsuyama, S., Hamada, M., Higashi, H., Nairn, A. C., and Greengard, P. (2003). Metabotropic mGlu5 receptors regulate adenosine A2A receptor signaling. Proc. Natl. Acad. Sci. U.S.A. 100, 1322-1327.

Novak, M., Halbout, B., O'Connor, E. C., Rodriguez Parkitna, J., Su, T., Chai, M., Crombag, H. S., Bilbao, A., Spanagel, R., Stephens, D. N., Schutz, G., and Engblom, D. (2010). Incentive learning underlying cocaineseeking requires mGluR5 receptors located on dopamine D1 receptorexpressing neurons. J. Neurosci. 30 , 11973-11982.

O’Connor, E. C., Crombag, H. S., Mead, A. N., and Stephens, D. N. (2010). The mGluR5 antagonist MTEP dissociates the acquisition of predictive and incentive motivational properties of reward-paired stimuli in mice. Neuropsychopharmacology 35, 1807-1817. 
Olive, M. F. (2009). Metabotropic glutamate receptor ligands as potential therapeutics for addiction. Curr. Drug Abuse Rev. 2, 83-98.

Popoli, P., Pezzola, A., Torvinen, M., Reggio, R., Pintor, A., Scarchilli, L., Fuxe, K., and Ferre, S. (2001). The selective mGlu5 receptor agonist CHPG inhibits quinpirole-induced turning in 6-hydroxydopaminelesioned rats and modulates the binding characteristics of dopamine D2 receptors in the rat striatum: interactions with adenosine A2A receptors. Neuropsychopharmacology 25 505-513.

Quiroz, C., Lujan, R., Uchigashima, M., Simoes, A. P., Lerner, T. N., Borycz, J., Kachroo, A., Canas, P. M., Orru, M., Schwarzschild, M. A., Rosin, D. L., Kreitzer, A. C., Cunha, R. A., Watanabe, M., and Ferre, S. (2009). Key modulatory role of presynaptic adenosine A2A receptors in cortical neurotransmission to the striatal direct pathway. ScientificWorldJournal 9, 1321-1344.

Reichel, C. M., Schwendt, M., Mcginty, J. F., Olive, M. F., and See, R. E. (2011). Loss of object recognition memory produced by extended access to methamphetamine self-administration is reversed by positive allosteric modulation of metabotropic glutamate receptor 5. Neuropsychopharmacology 36, 782-792.

Robbins, T. W., Ersche, K. D., and Everitt, B. J. (2008). Drug addiction and the memory systems of the brain. Ann. N. Y. Acad. Sci. 1141, $1-21$.

Rodrigues, R. J., Alfaro, T. M., Rebola, N., Oliveira, C. R., and Cunha, R. A. (2005). Co-localization and functional interaction between adenosine $\mathrm{A} 2 \mathrm{~A}$ and metabotropic group 5 receptors in glutamatergic nerve terminals of the rat striatum. J. Neurochem. 92, 433-441.

Romano, C., Sesma, M. A., Mcdonald, C. T., O'malley, K., Van Den Pol, A. N., and Olney, J. W. (1995). Distribution of metabotropic glutamate receptor mGluR5 immunoreactivity in rat brain. J. Comp. Neurol. 355, 455-469.

Rosin, D. L., Hettinger, B. D., Lee, A., and Linden, J. (2003). Anatomy of adenosine A2A receptors in brain: morphological substrates for integration of striatal function. Neurology 61, S12-S18.

Schiffmann, S. N., Fisone, G., Moresco, R., Cunha, R. A., and Ferre, S. (2007). Adenosine A2A receptors and basal ganglia physiology. Prog. Neurobiol. 83, 277-292.

Sesack, S. R., and Pickel, V. M. (1992). Prefrontal cortical efferents in the rat synapse on unlabeled neuronal targets of catecholamine terminals in the nucleus accumbens septi and on dopamine neurons in the ventral tegmental area. J. Comp. Neurol.320, 145-160.

Shigemoto, R., Nomura, S., Ohishi, H., Sugihara, H., Nakanishi, S., and Mizuno, N. (1993). Immunohistochemical localization of a metabotropic glutamate receptor, mGluR5, in the rat brain. Neurosci. Lett. 163, 53-57.

Simonyi, A., Schachtman, T. R., and Christoffersen, G. R. (2005). The role of metabotropic glutamate receptor 5 in learning and memory processes. Drug News Perspect. 18, 353-361.

Smith, A. D., and Bolam, J. P. (1990). The neural network of the basal ganglia as revealed by the study of synaptic connections of identified neurones. Trends Neurosci. 13, 259-265.

Smith, Y., Charara, A., Hanson, J. E., Paquet, M., and Levey, A. I. (2000). $\mathrm{GABA}(\mathrm{B})$ and group I metabotropic glutamate receptors in the striatopallidal complex in primates. $J$. Anat. 196(Pt 4), 555-576.

Sung, K. W., Choi, S., and Lovinger, D. M. (2001). Activation of group I mGluRs is necessary for induction of long-term depression at striatal synapses. J. Neurophysiol. 86, 2405-2412.

Svenningsson, P., Le Moine, C., Kull, B., Sunahara, R., Bloch, B., and Fredholm, B. B. (1997). Cellular expression of adenosine A2A receptor messenger RNA in the rat central nervous system with special reference to dopamine innervated areas. Neuroscience 80, 1171-1185.

Tallaksen-Greene, S. J., Kaatz, K. W., Romano, C., and Albin, R. L. (1998). Localization of mGluRlalike immunoreactivity and mGluR5like immunoreactivity in identified populations of striatal neurons. Brain Res. 780, 210-217.

Tatarczynska, E., Klodzinska, A. Chojnacka-Wojcik, E., Palucha, A., Gasparini, F., Kuhn, R., and Pilc, A. (2001). Potential anxiolyticand antidepressant-like effects of MPEP, a potent, selective and systemically active mGlu5 receptor antagonist. Br. J. Pharmacol. 132, 1423-1430.

Tebano, M. T., Martire, A., Rebola, N., Pepponi, R., Domenici, M. R., Gro, M. C., Schwarzschild, M. A., Chen J. F., Cunha, R. A., and Popoli, P. (2005). Adenosine A2A receptors and metabotropic glutamate 5 receptors are co-localized and functionally interact in the hippocampus: a possible key mechanism in the modulation of N-methyl-Daspartate effects. J. Neurochem. 95, 1188-1200.

Testa, C. M., Standaert, D. G. Landwehrmeyer, G. B., Penney, J. B. Jr., and Young, A. B. (1995) Differential expression of mGluR5 metabotropic glutamate receptor mRNA by rat striatal neurons. J. Comp. Neurol. 354, 241-252.

Torvinen, M., Kozell, L. B., Neve, K. A., Agnati, L. F., and Fuxe, K. (2004). Biochemical identification of the dopamine D2 receptor domains interacting with the adenosine A2A receptor. J. Mol. Neurosci. 24, 173-180.

Totterdell, S., and Smith, A. D. (1989). Convergence of hippocampal and dopaminergic input onto identified neurons in the nucleus accumbens of the rat. J. Chem. Neuroanat. 2, 285-298.

Traynor, J. (2010). Regulator of G protein-signaling proteins and addictive drugs. Ann. N. Y. Acad. Sci. 1187, 341-352.
Vilardaga, J. P., Nikolaev, V. O., Lorenz, K., Ferrandon, S., Zhuang, Z., and Lohse, M. J. (2008). Conformational cross-talk between alpha2Aadrenergic and mu-opioid receptors controls cell signaling. Nat. Chem. Biol. 4, 126-131.

Yao, L., Mcfarland, K., Fan, P., Jiang, Z., Ueda, T., and Diamond, I. (2006). Adenosine A2A blockade prevents synergy between m-opiate and cannabinoid CB1 receptors and eliminates heroinseeking behavior in addicted rats. Proc. Natl. Acad. Sci. U.S.A. 103, 7877-7882.

Zerbib, F., Keywood, C., and Strabach, G. (2010). Efficacy, tolerability and pharmacokinetics of a modified release formulation of ADX10059, a negative allosteric modulator of metabotropic glutamate receptor 5: an esophageal $\mathrm{pH}$ impedance study in healthy subjects. Neurogastroenterol. Motil. 22, 859-865, e231.

Conflict of Interest Statement: The authors declare that the research was conducted in the absence of any commercial or financial relationships that could be construed as a potential conflict of interest.

Received: 22 December 2011; accepted: 16 April 2012; published online: 07 May 2012.

Citation: Brown RM, Mustafa S, Ayoub $M A$, Dodd PR, Pfleger KDG and Lawrence AJ (2012) mGlu5 receptor functional interactions and addiction. Front. Pharmacol. 3:84. doi: 10.3389/fphar.2012.00084

This article was submitted to Frontiers in Neuropharmacology, a specialty of Frontiers in Pharmacology.

Copyright (c) 2012 Brown, Mustafa, Ayoub, Dodd, Pfleger and Lawrence. This is an open-access article distributed under the terms of the Creative Commons Attribution Non Commercial License, which permits non-commercial use, distribution, and reproduction in other forums, provided the original authors and source are credited. 